Copyright (C) 2021 The Author/s

This work is licensed under a CC-BY 3.0 License

Peer review method: Double-Blind

Accepted: August 08, 2021

Published: September 21, 2021

Original scientific article

DOI: https://doi.org/10.47305/JLIA2137196a

\title{
MIGRANTS AND THE PROLIFERATION OF SMALL ARMS AND LIGHT WEAPONS IN THIRD WORLD COUNTRIES: A STUDY OF NORTH-EASTERN NIGERIA SINCE 1999
}

\author{
Theophilus Oyime Adejumo* \\ Department of Political Science at the University of Calabar, Nigeria \\ ORCID iD: https://orcid.org/0000-0002-6275-5201 \\ theophilusoyime@gmail.com \\ Owa Egbara Owa \\ Department of Political Science at the University of Calabar, Nigeria \\ ORCID iD: https://orcid.org/0000-0003-4554-5568 \\ owaegbaraowa001@gmail.com

\section{Ojie Abang Peter} \\ Department of Political Science at the University of Calabar, Nigeria \\ ORCID iD: https://orcid.org/0000-0002-7325-9262 \\ ojiepee@gmail.com
}

\begin{abstract}
This study examines the effects of the proliferation of SALWs on the security of the Nigerian state. Although this issue has seldom been tackled in regular or academic literature, it reflects the author's keen awareness that, in an era of globalization, migrants have been identified as important agents in the proliferation of SALWs into third-world countries. The paper seeks to provide an insight into the socio-economic and political variables operating in the source and destination of such movements, with particular emphasis on migrants and arms proliferation. The study uses the qualitative approach for data analysis, it relies on upon, data gathered through secondary sources, and is reinforced with the argument on the liberal theoretical framework of analysis. The paper concludes that, while weapons play a significant role in intensifying conflict that exerts enormous human and economic costs, the causes of such conflicts lie in political, economic, ethnic, and religious differences and disparities. Finally, the paper looks at the appropriateness of examining the full implications of SALWs as a border management theme and the role of complementary measures for facilitating border control.
\end{abstract}

Keywords: Migration; Porous Border; Globalization; Proliferation 


\section{INTRODUCTION}

The subject matter of migration is central to the history of a people. This explains why in an attempt to understand the history of a people, where they come from, how they left where they come from, and why, are unavoidable questions to which answers must be provided. By migration here, we mean the movement of people from one place to another. Such movement is underpinned by the interplay of socio-economic and political variables operating in the source and destination of the movements. This is largely due to its tremendous impact on many contemporary global issues with farreaching implications for the international system particularly in an era of mounting environmental concerns, rapid technological breakthrough, widening political participation, and constantly redefined ideologies and political behavior among others, have in many ways, intensified human migration. Issues such as world peace and security, population drift and international labor mobility, growing pressure on world's natural resources, poverty, environmental degradation, and natural calamities, the international migration crisis, refugees and humanitarian needs, international crimes and syndicate, unemployment, territorial claims, and boundary disputes, power rivalry, famine, conflict, insecurity, porous borders, injustices, arms trafficking, armed banditry, activities of fundamentalists and forces of globalization. If relates to Nigeria, one would realize that they are prevalent and have serious consequences.

This study mirrors the author's strong cognizance that in an era of globalization, migrants have been recognized as important agents in the proliferation of Small Arms and Light Weapons (SALWs) into third-world countries. Nowhere is this assertion more apt than in Nigeria, especially in the north-eastern part of the country, where the activities of religious fundamentalists (Boko Haram, Islamic sect, the Fulani herders, and armed bandits) have plagued that part of the country into the worse socio-economic and political crisis the country has witnessed since the civil war. Scholars such as Theophilus (2019), Theophilus (2020), Olasile (2015), MuhammedLadan (2012), Malam (2014), Edeko (2011), Omede (2011), Okafor (2017), Ibeanu (2015), Small Arms Survey (2005), have aptly observed that people are directly affected by small arms use before, during and after conflicts. They further highlighted that SALWs proliferation sustains and worsens violent conflicts that threaten the functions of legitimate governments, as well as the provision of humanitarian assistance. However, these explanations can best be understood within the context of globalization and porous borders, which have catalyzed the movement of people and goods across international borders.

In tackling the problem of migration and SALW's proliferation, the Nigerian state depended on the following steps, as demonstrated by the establishment of the National Commission for the Control of Proliferation and Unlawful Circulation of Light Weapons (NATCOM) for the implementation of the ECOWAS moratorium in July 2006. The government also established the Program for Coordination and Assistance for Security 
and Development (PCASED) in March of that year. Similarly, the Nigerian state has also been cooperating with neighboring states such as Niger, Chad, Benin Republic, and Cameroon on cross-border crime to enhance security on Nigeria's international borders by the police, customs, and immigration officers to check the movement of people in and out of Nigeria. Globally, Nigeria is a signatory to the United Nations Fire Arms Protocol of November 13, 2001, which was ratified on July 15, 2004.

Equally, a myriad of other groups - IGOs/NGOs, AU (African Union), SAD (South African Development Agency), WANSA (West African Network on Small Arms), Civil Society Organisations, etc. have all taken major steps to find an effective and lasting solution to address the problem of migration and arms proliferation. Unfortunately, despite the existence of regional, continental and international instruments designed to curb the spread of SALWs from neighboring states into North-Eastern Nigeria, the country has continued to witness the influx in geometric terms of SALWs by illegal immigrants. Without going into a detailed analysis yet, it is imperative to provide a brief historical background of the study areas to provide a basis for the understanding of this paper. The political zone referred to as North-Eastern Nigeria comprises the states of Adamawa, Bauchi, Borno, Gombe, Taraba, and Yobe. Ibrahim (2012) argued that the area that constitutes the North-Eastern Zone of Nigeria lies between the vast and expanse of the Sahara and the dense tropical rainforest along the Guinean coast. Delimiting the area is Cameroon to the east, Niger and the Chad Republic to the North, North-Central Nigeria on the West, and South-Eastern Nigeria to the South. According to Nyako Abdul-Aziz (2015), the North-East occupies slightly less than one-third of Nigeria's total area and has a projected population of $23,558,674$ or $13.5 \%$ of the country's population. This important location has profound implications for the country's security strategies ranging from immigration policy, customs and, labor laws. The paper presented by Muhammed T. Ladanin (2012), points to the fact that, since 1985, the North-East has retained the title of the poorest zone in Nigeria, with the highest incidence of poverty (ranging between $54.99 \%-72.2 \%$ ). It is also the zone with the highest number of internally displaced persons (IDPs), totaling 11,360 in the first quarter of 2012 and 20102011 with the highest number of forced displacement of internally displaced persons (IDPs) (approximately $22 \%$ or 82,000 ). Moreover, the North-East has also been described as the home or paradox of Boko-Haram (literally transmitted 'Jama'atu Ahlis-Sunna Lidda'Awati Wal-Jihad) an armed group that promotes sectarian violence of different dimensions that have engulfed the entire region, in the history of Nigeria - that is, neither inter- nor intra-religious but essentially against the Western-educated Muslim elite and government. In his presentation, Muhammed T. Ladan further argued that it is a paradox such a movement that is opposed to the acquisition of knowledge emerged in Borno State, the capital of Kanem-Borno Empire and the first Islamic state in precolonial Nigeria that was established based on knowledge and excellence in scholarship, resulting in the movement distortion. He argued further that, it is a paradox that such a 
situation should emanate from the minds of those who believe that they are asserting their religious identity, reforming Islam and restoring it to its pristine purity by maiming and killing innocent residents, destroying property, and rupturing peace. This explains why from a historical perspective, the zone shares geographical proximity and cultural affinities, which makes migration across the existing borders easy. The Hausa-FulaniKanem-Borno cut into Nigeria, Niger and Chad. These characteristics make this zone vulnerable to migrants and illegal trafficking in SALWs. It is based on this that one can understand the changing nature of the security scenario in West Africa and NorthEastern Nigeria in particular.

\section{LITERATURE REVIEW}

Causes and Channels of SALWs Proliferation

In the course of this study, several works which contain relevant information on the origin, causes, transit, destination, threat, and risk of SALWs to the security of states in Africa and Nigeria in particular, in the period under review, have been consulted. However, Theophilus (2020), Okafor (2017), Banko (2016), Lamptey (2013), Onwuka (2010), Hazeban and Horner (2007), Abdel-Fatau (2002), Kofi (2002), among others have undertaken a comprehensive discussion on this. According to them, the Nigerian state has been and is still being threatened on many fronts by violence that is being perpetrated with the use of small arms and light weapons, which are freely deployed.

There are rarely any geopolitical zones of Nigeria without its major share of armsrelated threats to peace, security, and development that is either ongoing or recently resolved. Okafor (2017) and Theophilus (2020) acknowledged the view that several works contain relevant information on the origin, causes, sources, transit, and destination of SALWs in Nigeria in general, and the North-Eastern states, in particular, have been consulted. Onwuka (2010) has argued that trafficking by migrants is not entirely new in the global discourse. He however argued further that, the focus on it took an unprecedented turn at the end of the Cold War when the iron curtain across Europe was dismantled. Therefore, with the triumph of free markets and the enthronement of unipolar political and economic world view, arms trade experienced phenomenal deregulation. This deregulation process promoted exponentially the availability of SALWs in Africa at costs that were suddenly affordable to those who hitherto stood no chance of procuring the weapons. Along the same line, Abdel-Fatau (2002) argued that, in Africa, factors responsible for the proliferation of SALWs are many and varied. While the thrust of international efforts to curb proliferation tends to concentrate on the manufacture and supply of new weapons. Accordingly, he further noted, a major pipeline remains the stockpiles that were pumped into Africa in the 1970s, 1980s, and early 1990s by the ex-Soviet Union, the USA, and allies to fan proxy 
intra-state and inter-state wars. Equally, Banko's (2016) central argument is that those left-over weapons have found their way through clandestine networks involving illegal migrants, rogue arms brokers, private military companies, and shady airline companies, such as Victor Bout, who owns five (5) airlines that flew sixty (60) aircraft and employed some three hundred (300) migrants who serve as a network provider in bridging the gap in the chain of supply of arms to destination points, and Leonid Effimonich, a major broker and dealer in arms, indicted over the proliferation of arms in West Africa, as well as Geza Mezosy, a Belgian who established a company, 'Eastronition' through which he sold illegal arms across Belgium, Luxembourg and Hungary, and ran dirty arms deals and sponsored many cliques and merchants of arms dealers and gangs to exacerbate ongoing conflicts and facilitate the start of new ones in the continent.

In Nigeria's Niger Delta region, Henry Okah, MEND's leader, is a known arms broker with great leverage and monopoly of sorts over the Nigeria-South Africa arms trafficking axis. A report credited to GIABA in 2013, noted that Asari Dokubo, another MEND leader, once reported that Okah had supplied him arms, including AK-47s, general-purpose machine guns, cans of bullets, G3, and RPGs to conduct a series of violent attacks against government targets in the Niger-Delta.

Hazebn and Horner's (2007) position is that, although the operations of these and similar groups are shrouded in mystery, their activities supported corrupt regimes, contributed to the use of child soldiers, and fuelled endless wars and insurrection in West Africa. These, according to Hazebn and Horner, are common occurrences in Nigeria, as was the case in most other countries including Iraq, Libya, Syria, Sudan, Egypt, Yemen, etc.

In all, it must be acknowledged that the breakup and deregulation of arms industries in Eastern and Central Europe have also led to the mushrooming of mini-arm industries in Africa whose aggressive search for new markets in the developing world has made nonsense of existing export regimes. Africa itself boasts of countries that are arms manufacturers - South Africa, Zimbabwe, Egypt, Morocco, and Nigeria, among others, are countries dotted with growing SALW's cottage industries. As a consequence, small arms have found their way into civilian hands from official sources due to a combination of factors, including the breakdown of the state structures, lax controls over national armories, and poor service conditions for security personnel.

This horrifying situation has led Langumba (2010) to further acknowledge that; "the widespread availability of small arms to abusive actors poses a threat of unprecedented magnitude to West Africa, far greater than that of HIV/AIDS in terms of its socio-economic and human consequences". Put simply;

small arms and light weapons constitute a category of weapons responsible for most of today's conflict casualties and human rights abuses worldwide. Small arms proliferation is not merely a security issue, it is also an issue of human rights and development. The proliferation of 
SALWs sustains and intensifies armed conflicts. It endangers peacekeepers and workers. It undermines respect for international humanitarian laws; it threatens legitimate but weak governments and it benefits terrorists as well as the perpetrators of organized crime (Kofi 2002).

Lamptey (2013) established the fact that, following the radicalization processes and the collapse of state structures that characterize the Arab Spring, loosened up weapons became easily available to leaders of the present militant groups in Nigeria who found fertile enclaves for training in these countries. It must however be established that these weapons were massively brought into Nigeria for use in most insurgencies, especially the Boko Haram upheaval, armed banditry, Fulani herders. It is glaring from reports of the Nigerian military in Sambisa forest, that there were skilled mercenaries who came into Nigeria along with these arms to train recruits on the use and operation of these SALWs. Nagbanton Patrick in GIABA Report (2013) reaffirmed this argument that Boko Haram acquires arms from Niger, Chad, and Cameroon countries that share borders with Nigeria in the northern part of the country. Nigeria's extensive borders with Cameroon, notorious as smuggling routes for illicit SALWs, perfectly serves the purpose of Boko Haram, especially with the Northeast being its primary base. With most of its original members hailing from the northeast, the group easily facilitates the flow of illicit SALWs from Chad into Nigeria. Indeed, the use of AK47 rifles to carry out attacks is an indication that most of the arms used by the group were smuggled into the country. For instance, during the April 2011 general elections, the police and other security agencies recovered and seized 3 AK-47 rifles and other arms from Boko Haram in a raid in Maiduguri. The group also uses locally manufactured firearms and produces explosives in one of its hideouts in Bauchi State (Next Newspaper, 4 August 2009). The cases of looted state arsenals by civilians, whether in Albania in 1977, Uganda in 1979, or Iraq in 2003, emphasize how easily small arms quickly enter the illicit sphere and become difficult to track. They easily percolate because they are small arms, easy to buy, use and conceal. Their proliferation intensifies conflict, sparks refugee flows, undermines the rule of law, and spawns a culture of violence and impunity. These looted arms end up, one way or another, in vulnerable countries like Nigeria. In the same vein, Oshita (2010) observed that, through some peace missions involving the Nigerian military in the West African sub-region, many of SALWs come into wide circulation in the country. It is widely held that some discharged soldiers from war zones in Liberia and Sierra Leone had returned to the country with various types of ammunition used in wartime, and sold weapons in the country for cheap money. Indeed, some weapons captured by the police from criminals, migrants, and militia members have been identified to these various peace mission exercises in the sub-region. Having recognized the corrosive effects of SALWs proliferation on human and physical development in Nigeria, Imobighe Thomas in Edeko Sunday (2011) 
reported that there are many reasons why Nigeria is such a willing and functional receptacle or repository of SALWs. Borders inherited by Nigeria are badly demarcated, hence they are easily crossed. These boundaries were arbitrarily drawn by European imperialists who colonized almost the entire African continent. In his report, he noted that a tour of the Nigerian borders in September 1984 by Nigerian Immigration officials in Sokoto revealed that there were more than 1,500 illegal entry points along Nigeria's border with Benin and Niger. He further reported that Nigeria shares a long stretch of land border with the Republic of Niger and Chad in the North, Benin Republic in the West, and Cameroon in the East, in addition to a long stretch of Atlantic coastline. Each of these frontiers provides entry points for systematic smuggling of arms into the country.

Banko (2016) aligns with the view that currently in Nigeria, it is on record that the two most notorious arms smuggling frontiers in Nigeria are Idi-Iroko and Seme in the South-Western state of Lagos. One may not know the statistics of SALWs in circulation in Nigeria, but one indisputable fact is that the percentage is high. Other reported countries from which illegal weapons and ammunition are sourced include Cote d'Ivoire, Liberia, South Africa, Turkey, and Ukraine, as well as Bulgaria, Kosovo, and Serbia. While source countries are often named, the flow of SALWs from source and transit countries is not well documented.

Nigerian state in general and the North-Eastern states, in particular, are riddled with abject poverty, high unemployment rate, social deprivation and injustice, pollution, and underdevelopment. The synergy between the aforesaid has created a breeding ground for non-state armed groups, organized crime and illicit trafficking, and the proliferation of SALWs. Put differently, because the Nigerian youths remain permanently agitated and anxious about the future, they resort to 'any means possible or available' to eke a living. This anchored on a general culture of impunity and crass materialism heightens crime, especially amongst a young generation that feels hopeless and helpless. It is precisely in this scenario that the search for and acquisition of SALWs is construed as the sure means of opening doors to a better tomorrow by these frustrated and misguided youths.

This situation is worsened by the failure of the government to provide the muchneeded security is a factor that compels citizens to look for an alternative. Several studies have shown that lack of confidence in security forces or the inability of security agencies to carry out their duty effectively in many African countries and Nigeria, in particular, informed the strong need by citizens to acquire arms to protect themselves and their property from armed violence. In addition to the failure of the government to provide the much-needed security, Africa is equally laden by the devastating impacts of climate change, which will heighten the threat to regional security, most especially in West Africa. Jakkie Cilliers in Okafor (2017) noted that climate change presents humanity with its largest challenges in recorded history. Its predicted effects over the coming 
decades include extreme weather events, droughts, flooding, rising sea levels that could affect countries such as Nigeria and Mozambique ...changes in habitats, and increased spread of life-threatening diseases such as malaria. Today Africa is home to the most rapid levels of population growth and urbanization in the world and will shortly have more people than China. Already it is inhabited by 14 percent of the world's human population. Africa will inevitably face greater challenges owing to climate change than any other region.

Lastly, the forces of globalization bring opportunities and challenges. The increasing and complex global system of production and exchange, and the elimination of state-enforced restrictions on the movement of goods and services across borders, further complicate the challenges of containing SALWs proliferation.

Table 1: Types, Sources, Routes, and Destinations of SALW in West Africa (Source: GIABA Report 2013)

\begin{tabular}{|c|c|c|c|}
\hline $\begin{array}{c}\text { Country of Destination } \\
\text { or Use }\end{array}$ & Types of SALW & $\begin{array}{l}\text { Likely Countries of } \\
\text { Origin/Suppliers }\end{array}$ & Means/Routes \\
\hline Niger & $\begin{array}{c}\text { AK-47 guns, pistols, } \\
\text { short, long, and double- } \\
\text { barrel guns, Beretta } \\
\text { guns, and Kalashnikov } \\
\text { rifles }\end{array}$ & $\begin{array}{c}\text { Libya, Chad, Somali, } \\
\text { Sudan, Nigeria, Algeria, } \\
\text { Burkina Faso, and local } \\
\text { manufacturers }\end{array}$ & $\begin{array}{l}\text { Land borders and } \\
\text { footpaths }\end{array}$ \\
\hline Guinea Bissau & $\begin{array}{c}\text { AK-47 guns, pistols, } \\
\text { short, long, and double- } \\
\text { barrel guns }\end{array}$ & $\begin{array}{l}\text { Remnants from the } \\
\text { independence struggle, } \\
\text { Liberia, Sierra Leone, } \\
\text { and local manufacturers }\end{array}$ & Land and sea borders \\
\hline Cote d'Ivoire & $\begin{array}{l}\text { AK-47 guns, pistols, } \\
\text { revolvers, assault rifles, } \\
\text { short, long, and double- } \\
\text { barrel guns }\end{array}$ & $\begin{array}{c}\text { Liberia, Guinea, USA, } \\
\text { Britain, Russia, France, } \\
\text { China, and local } \\
\text { manufacturers }\end{array}$ & Land and sea borders \\
\hline $\begin{array}{l}\text { Nigeria (Niger Delta, } \\
\text { North-East) }\end{array}$ & $\begin{array}{l}\text { Pump-action guns, AK- } \\
47 \text { guns, revolvers, self- } \\
\text { loading guns, assault } \\
\text { rifles, pistols, short, long, } \\
\text { and double-barrel guns }\end{array}$ & $\begin{array}{l}\text { Chad, Cameroon, South } \\
\text { Africa, Europe, Nigeria } \\
\text { Military and police } \\
\text { officers, local } \\
\text { manufacturers, Great } \\
\text { Lakes region, and Russia }\end{array}$ & $\begin{array}{l}\text { Land and sea borders, } \\
\text { creeks, and airstrips }\end{array}$ \\
\hline Togo & $\begin{array}{l}\text { AK-47 guns, local } \\
\text { pistols, and long rifles, } \\
\text { pistols, short, long, and } \\
\text { double-barrel guns }\end{array}$ & $\begin{array}{l}\text { Nigeria, Ghana, and } \\
\text { local manufacturers }\end{array}$ & $\begin{array}{l}\text { Land borders, } \\
\text { footpaths }\end{array}$ \\
\hline Ghana & $\begin{array}{l}\text { Pistols, AK-47 guns, } \\
\text { revolvers, pump-action } \\
\text { guns, short, long, and } \\
\text { double-barrel guns }\end{array}$ & $\begin{array}{c}\text { Remnants of the military } \\
\text { era and local } \\
\text { manufacturers }\end{array}$ & \\
\hline Sierra Leone & $\begin{array}{l}\text { AK-47 guns, revolvers, } \\
\text { rockets, self-loading }\end{array}$ & $\begin{array}{c}\text { Guinea, Liberia, Cote } \\
\text { d'Ivoire, remnants of the }\end{array}$ & $\begin{array}{l}\text { Land, sea borders, and } \\
\text { footpaths through }\end{array}$ \\
\hline
\end{tabular}




\begin{tabular}{|c|c|c|c|}
\hline & $\begin{array}{l}\text { pistols, rifles, assault } \\
\text { rifles, locally made guns, } \\
\text { mortars, and hand } \\
\text { grenades }\end{array}$ & $\begin{array}{l}\text { civil war, and local } \\
\text { manufacturers }\end{array}$ & Guinean forest \\
\hline Liberia & $\begin{array}{l}\text { AK-47 guns, revolvers, } \\
\text { self-loading pistols, } \\
\text { rifles, assault rifles, } \\
\text { locally made guns, } \\
\text { mortars, and hand } \\
\text { grenades }\end{array}$ & $\begin{array}{l}\text { Guinea, Burkina Faso, } \\
\text { East Europe, Libya, } \\
\text { remnants of the civil } \\
\text { war, local manufacturers }\end{array}$ & Land and sea borders \\
\hline $\begin{array}{l}\text { Senegal } \\
\text { (Casamance Region) }\end{array}$ & $\begin{array}{l}\text { AK-47 guns, pistols, } \\
\text { rockets, short, long, and } \\
\text { double-barrel guns }\end{array}$ & $\begin{array}{l}\text { Guinea Bissau, Gambia, } \\
\text { Iran, and local } \\
\text { manufacturers }\end{array}$ & $\begin{array}{l}\text { Land borders, maritime } \\
\text { borders, and footpaths }\end{array}$ \\
\hline Gambia & $\begin{array}{l}\text { AK-47 guns, pistols, } \\
\text { rockets, short, long, and } \\
\text { double-barrel guns }\end{array}$ & $\begin{array}{l}\text { Local manufacturers, } \\
\text { Iran and Senegal }\end{array}$ & Land and sea borders \\
\hline Burkina Faso & $\begin{array}{l}\text { AK-47 guns, revolvers, } \\
\text { self-loading pistols, } \\
\text { rifles, assault rifles, and } \\
\text { locally made guns }\end{array}$ & $\begin{array}{l}\text { Liberia, Cote d'Ivoire } \\
\text { and local manufacturers }\end{array}$ & $\begin{array}{l}\text { Land borders and } \\
\text { footpaths }\end{array}$ \\
\hline Guinea & $\begin{array}{c}\text { AK-47 guns, local } \\
\text { pistols, and long rifles, } \\
\text { short, long, and double- } \\
\text { barrel guns }\end{array}$ & $\begin{array}{l}\text { Local manufacturers, } \\
\text { Cote d'Ivoire, Sierra } \\
\text { Leone, and Liberia }\end{array}$ & Land and sea borders \\
\hline Cape Verde & $\begin{array}{l}\text { AK-47 guns, revolvers, } \\
\text { assault rifles, long and } \\
\text { double barrel guns }\end{array}$ & $\begin{array}{l}\text { Europe and local } \\
\text { manufacturing }\end{array}$ & Sea borders \\
\hline Benin & $\begin{array}{l}\text { AK-47 guns, revolvers, } \\
\text { assault rifles, long and } \\
\text { double barrel guns }\end{array}$ & $\begin{array}{c}\text { Nigeria, Togo, South } \\
\text { Africa }\end{array}$ & Land and sea borders \\
\hline Mali & $\begin{array}{l}\text { AK-47 guns, revolvers, } \\
\text { assault rifles, long and } \\
\text { double barrel guns }\end{array}$ & $\begin{array}{l}\text { Local manufacturers, } \\
\text { Niger, Libya, Algeria, } \\
\text { and Mauritania }\end{array}$ & Land borders \\
\hline
\end{tabular}




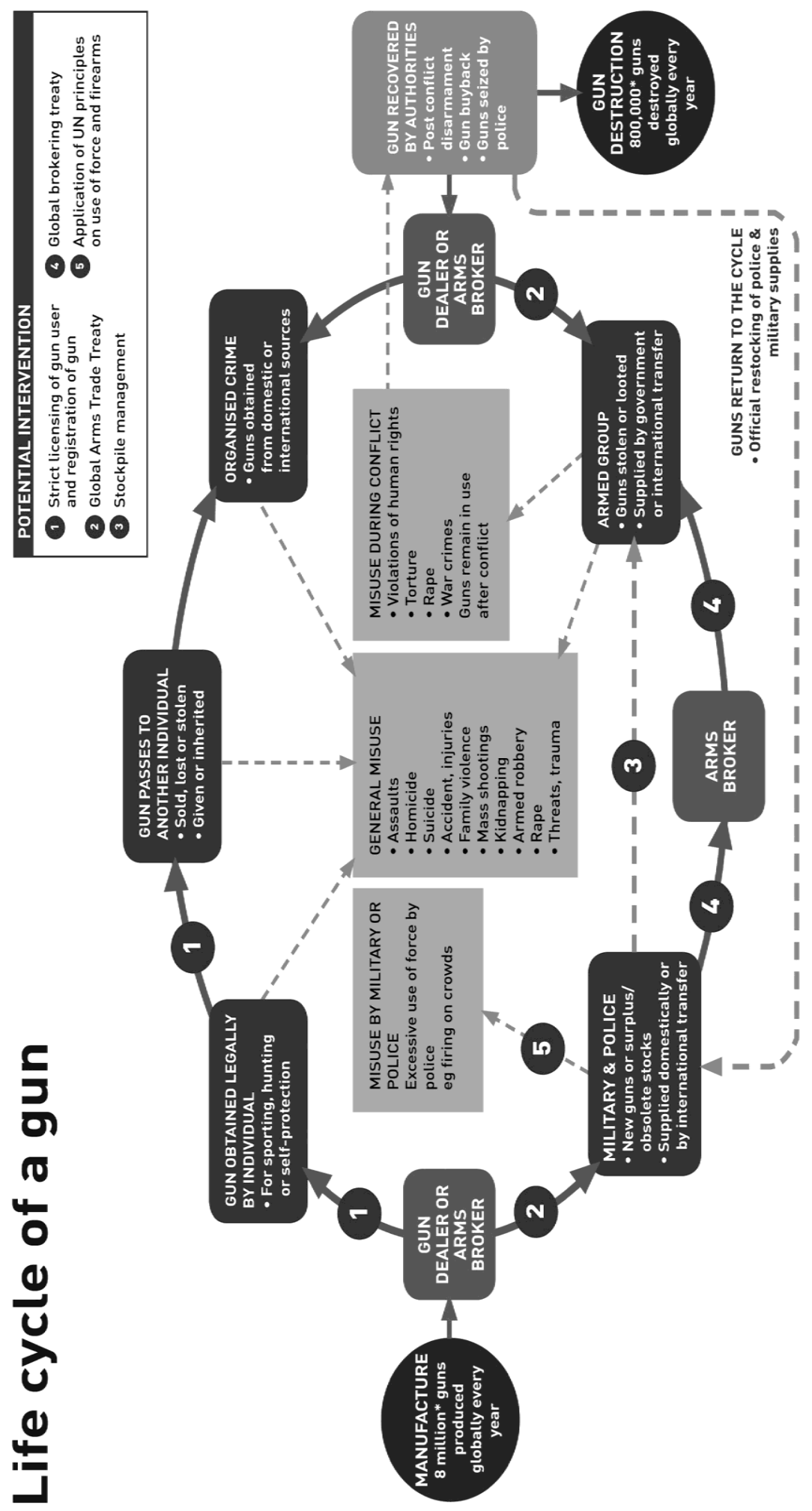

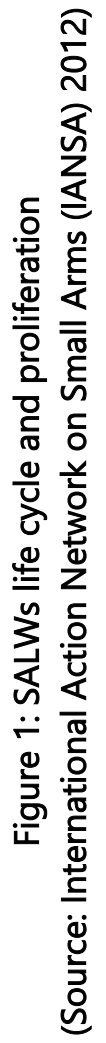




\section{Existing Control Measures on Arms Tracing/Proliferation}

It has been argued severally at different fora that political instability and security in West Africa and Nigeria are driven by the untamed movement of SALWs in the region. This trend constitutes a major humanitarian challenge and crisis in the region. It has been observed that the availability and easy procurement of SALWs by non-state actors, especially warmongers and human rights abuses are, to a large extent, responsible for a great number of civilian causalities in West African civil conflict, and nay Africa at large (Koroma 1999). Thus, the proliferation of SALWs is a major challenge across the globe.

Given this, the international community under the auspices of the United Nations has explicitly noted that arms tracing remains a critical component of any meaningful collective response to addressing the challenges posed by the illicit proliferation of SALWs. This according to Okafor (2017) was the basis for the negotiation and adoption of a distinct International Tracing Instrument (ITI) titled "the international instrument to enable states to identify and trace, in a timely and reliable manner, illicit SALWs in December by 2005 by the Member States of the UN.

Evaluating SALWs control measures initiated by various regional bodies, the West African sub-regional organization amplified the importance of tracing in the ECOWAS convention on SALWs, signifying an endorsement of the earlier position of memberstates in all the UN arms control instruments. The instruments apportioned critical responsibility on states bearing in mind that the military-industrial complexes that manufactured these weapons are being housed by states. Therefore, as a requirement for an effective arm-tracing, the state has to ensure that arms manufactured within its jurisdiction are properly marked.

Bah (2004) argued that the ECOWAS moratorium is one of such initiatives targeted at solving the security challenges posed by the proliferation of SALWs. In recognition of the danger that the proliferation of illicit small arms poses to the security of the nation. He argued further that ECOWAS under the stewardship of Mali which had undertaken successful peace negotiations with Tuareg rebels adopted a moratorium on the importation, exportation, and manufacture of small arms and light weapons in West Africa.

Put differently, in 2006 this was transformed into a legally binding instrument the ECOWAS Convention on SALWs, which came into force on September 29, 2009. In 2006, the ECOWAS Commission also launched a small arms program (ECOSAP) based in Bamako, Mali, as a capacity-building program for member-states and civil society organizations to deal with the problem of proliferation. To help implement and monitor ECOWAS policy and regulation on the issue, it established a Small Arms Division within the commission. 
Although thirty-five years after the adoption in 1979, protocol relating to the free movement of persons, the Right of Residence and Establishment, several factors are still impeding effective inter-regional mobility within the ECOWAS region. Member states face a significant delay in transposing the 1979 protocol and supplementary protocols into law. While the right of entry and the abolition of visa requirements for a 90 -day stay have been implemented in all countries, less progress can be noted regarding the Right of Residence, the Right of Establishment, and access to employment.

West Africa is characterized by - among other factors - a fast-growing population and steadily increasing urbanization. These factors affect migration patterns in the region and require collective responses by member-states that work together in the framework of the regional integration process launched almost forty years ago through the Economic Community of West African States (ECOWAS). However, recently, member states have shown a growing interest and readiness to handle challenges related to migration as well as to better take advantage of the inherent development potential of migration (ECOWAS Report, 2016).

At the $33^{\text {rd }}$ ordinary session of Heads of States and Government of ECOWAS member states in January 2008, the ECOWAS Common Approach on Migration was officially endorsed. The key principle of the common approach is the free movement of persons within ECOWAS is key to the integration policy of the commission that regular migration towards other regions of the world contributes to the development of ECOWAS member states, hence the need to control irregular migration, SALWs trafficking, and human trafficking - particularly of women and children - and to promote dialog between ECOWAS host communities and transit countries (Ladan 2012).

\section{THEORETICAL DISCOURSE}

The establishment of an appropriate theoretical framework is an imperative necessity in any oriented research, not only because of the explanatory power of theories but also because such a theoretical frame would provide a guide that would enhance the understanding of the work as a whole. In this regard, two theories are used in this study: Realism and Liberalism.

The epistemic value of Realism is rooted in the assumption it makes: first, the states are the only actors in the international system; and second, the international environment is anarchic. This sense of anarchy is not that it lacks order or is chaotic, but that it lacks a world government with the potency to guarantee the security of states. Therefore, in a bid to guarantee her security, bolster its security and political power, states strive to safeguard their security by arms build-up. This explains why Morgenthau (1943) defines international politics as the struggle for power. It must however be emphasized that the lack of a world government as mentioned earlier does not imply the absence of international law, but the extent to which states will accept or reject 
international law will be to the extent to which they are willing to accept the consequences of such acceptance or rejection. Exponents of Realism include Kennan (1954), Morgenthau (1943), Kegley (1994), Waltz (1979) among others; framed an intellectual movement whose ideas and beliefs about the international system were opposed to idealism. In their conceptualization, the world is anarchy - a threat system in which force remains the ultima ratio, the "basis of diplomacy and all the contractual obligations beyond the boundaries of the state" (Theophilus 2019). As Michael Howard in Bassey $(2012,452)$ has argued, the "capacity of states to defend themselves and their evident willingness to do so, provides the basic framework within which the business of international negotiations is carried on".

The aim of Realism in this work is to show that, contrary to the conventional view inherited from the cold war era, whether developed or less developed nations, all are vulnerable to the security threat. What can be deduced from an analysis of the foregoing is that the manufacturing of arms by developed nations, to safeguard their security can at best can explain why weapons are proliferated to developing nations. GIABA Report of 2013 shows that most of the so-called small arms and light weapons used in recent conflicts are manufactured by the big industrialized nations. In Afghanistan, for example, the Taliban make use of Russian and American-made AK-47, RPG 7, USM 72, and automatic rifles.

A major deficiency of Realism is its assumption that states are the only actors in the international system. To this extent, the proliferation will follow an asymmetrical relationship between states. However, while states may be major actors in the international system, non-state actors, such as terrorist organizations, rogue arm brokers, private military companies, shady airline companies, and local smugglers, play a critical role when it comes to the proliferation of small arms and light weapons across nations, to exacerbate ongoing conflicts and facilitate the commencement of new ones in the continent.

From the above perspective, there is no doubt that Realism has a pessimistic view of the international system. Given the prevailing patterns of conflicts in inter-state relations, characterized by incessant competition, states are seen as the defining element of global reality. Accordingly, all necessary weapons are easily deployed by states to secure their paramountcy in the comity of nations. Hence the constant possibility of war and the resultant demands for Small Arms and Light Weapons (SALWs) in particular and other weapons of war at large. Thus, it may be said that the Realist theory will at best provide a necessary, but not sufficient explanation for the proliferation of SALWs. It is this deficiency that has necessitated this study to turn to the theory of Liberalism.

On the other hand, Liberalism is a theory that relates events to their likely causes. The theory is predicated on an economic view: That states should take their hands off the production and determination of prices of basic commodities, and allow the forces 
of demand and supply to determine prices of goods. It also advocated for the ownership of private properties rather than state ownership and control of the economy. Exponents of Liberalism including Keohane and Nye (1989), Rosenau (2004), John Locke, among others, have attributed the causes of the proliferation of SALWs to many factors: first, that the stockpiles that were pumped into Africa in the 1970s, 1980s and early 1990s by the ex-Soviet Union, the USA and their allies to fan proxy intra-state and inter-state wars. Second, the breakup and deregulation of arms industries in Eastern and Central Europe have led to the mushrooming of mini-industries in Africa whose aggressive search for new markets in the developing world have made nonsense of existing export regimes. For example, Africa itself boasts of countries that are arms manufacturers - South Africa, Nigeria, Morocco, Zimbabwe, Egypt, among others, are countries dotted with growing SALWs cottage industries. Third, the post-cold war scenario, according to Robert Kaplan, 'The Coming Anarchy Shattering the Dreams of the Post-Cold War', engendered severe adverse economic and political difficulties for many developing countries that cost their subsidies due to the sudden end of the regime of ideological proxies. The inability of these states to contain the new liberal onslaught resulted in violent intra-state conflicts.

The relevance of Liberalism to this study is to show that, contrary to the Realist conception that proliferation of SALWs is enhanced by state actors, the Liberal theorists are of the view that the idea of privatization which is factored in the theory of Liberalism that has allowed and encouraged individuals and private military companies to delve into the production and the manufacture of SALWs and their related spare parts at costs that were suddenly affordable to those who hitherto stood no chance of procuring these weapons, intending to make profits. In the US, for instance, like other developed countries, the military-industrial complex has been privatized, and other smaller corporations are at liberty to produce weapons and spare parts. It is this growing and uncontrolled production and trade in SALWs in the last few years, among regions suffering from political instability and violent conflicts that have made individuals and groups vulnerable to proliferation.

From the above, it can be said that the liberal theory is a better theory on which this study is anchored. For one thing, it provides a better explanation for the sources of proliferation (which in this case results in the privatization of the security system) and points to a direction in which the problem can be resolved (state taking absolute control and management of the security of states). From this standpoint, the study has adopted the theory of Liberalism as the theoretical framework. 


\section{RESEARCH METHODS AND DATA COLLECTION}

The data used for the analysis are based on information obtained from many sources. First, extensive desk research on institutional and official documents from the Nigerian Ministry of Defence, United Nations publications, Federal Office of Statistics, ECOWAS reports, and the University of Calabar library, was carried out on the policies of the various tiers of government as they impact on the political and peace processes in general, and on the proliferation of small arms and light weapons in particular, gleaned from various primary sources including Nigerian dailies and magazines. Secondly, data were obtained from elaborate Focus Group Discussions and content analysis involving border guards agencies: Army, Navy, Police, Customs, Immigration as well as Port Health Service and Nigerian Agricultural Quarantine Service (NAQS), including civil society spokesperson and some leading members of armed groups at the Seme Border post between Nigeria and Republic of Benin in August 2017, further illuminated the various perspectives on government's role in the propagation of small arms and light weapons in Nigeria.

The process of content analysis involved investigation, recording, and analyzing past events to discover generalizations that were significant in understanding the past and present to deal with the issues under consideration and make needful predictions and conclusions for the future, where applicable and necessary. The Focus Group Discussions clarified some of the questions that had been raised in the course of the desk research, and also identified areas for further research concerning the roles of state institutions in the proliferation of small arms and light weapons in Nigeria. Some members of the focus groups also drew the researcher's attention to documents on the internet, which they considered relevant to the subject matter.

\section{ANALYSIS AND DISCUSSION}

The Nigerian state has been and is being threatened on many fronts by violence that are being perpetrated with the use of small arms and light weapons, which are freely deployed. There is rarely any geopolitical zone of Nigeria without its major share of arms-related threats to peace, security, and development that is either ongoing or recently resolved. The underlying issues that generate these threats are internally induced, sometimes arising from the inherent contradictions of state-building that are often executed, using the instrumentality of violence. Okafor (2017) aligns with the view that Nigeria currently labors under the yoke of far too many conflicts of varying levels of intensity, and that the fault lines of these conflicts are socio-cultural even though rooted in the severe competition for scarce political, social, and economic resources. Paradoxically, while the conflict crises are driven internally, the instruments of their violent prosecution have predominantly remained SALWs that are sourced externally. 
The return to democratic rule since 1999. The Nigerian state and the northeastern states, in particular, are increasingly ruined by the availability and easy accessibility of SALWs by non-state actors who are desperately pursuing their parochial interests to the detriment of peace, security, and development. A new dimension to the conflict trends in the northeast is the activities of the Fulani militants mostly herdsmen who are armed with SALWs and are always ready to deploy them against their perceived enemies. The dastardly attacks of terror using SALWs allegedly committed by Fulani herdsmen in recent times have received international attention with the designation of them as being among the five most deadly terrorist groups in the world. In 2015, the Institute for Economics and Peace argued that Fulani herdsmen were responsible for the death of over 1,229 people in 2014, and have continued to pose a serious threat to the stability of the country. The conflict persists over the herdsmen's search for access and control of land and water. Equally, the northeastern states of Borno, Yobe, and Adamawa have been the epicenters of Boko Haram terrorism in Nigeria. The Boko Haram acclaimed by the 2015 Global Terrorism Index as the deadliest terrorist organization in the world, is renowned for the use of improvised explosive devices (IED) as well as the acquisition and indiscriminate use of SALWs.

In the South-Eastern State, the impact of SALWs proliferation is felt in the increased incidences of kidnapping for ransom, armed robbery, cultism, and communal crisis. For instance, the killing of people in rural communities in Enugu State by the Fulani herdsmen/militias has been enlisted in arms-related security challenges in the area. In the Niger-Delta region alone, about one hundred militant groups existed before the federal government's amnesty program (Asuni 2009). Although the North-Western states have been experiencing violent conflicts that showcase the lethality of SALWs in the hands of non-state actors, especially armed bandits, religious fundamentalists, and terrorists.

Unfortunately, in all these cases, the common attribute of these non-state armed groups remained their easy access to and indiscriminate use of SALWs. This depicts the vulnerability of the civil population and further highlights the enormity of the threats being faced by the Nigerian state. It equally pointed to the fact that states' institutional capacity, including the civil society, in confronting these challenges are weak, thereby continuously making it possible for the non-state actors to freely acquire and use SALWs. However, Theophilus, Ndum, and Abong (2020) aptly observed that the consequence of these and related security threats are the intermittent outbreak of violent conflicts in recent times. The failure of public security in Nigeria, and perhaps in the North-East has led the citizens to indulge in different forms of 'self-help' security measures ranging from vigilante groups to community-owned arms stockpiling. Having lost confidence in the Nigerian state, parties involved in some of these crises in Nigeria and the North-East, in particular, have become entangled in a security dilemma. The quest to procure more arms to guarantee personal and community protection from 
perceived and real enemies (Boko Haram, Fulani herders, armed bandits) is fuelling the domestic arms race. Hence, breaking the chain of SALWs circulation has remained a major challenge to the Nigerian government. This unfortunate situation in turn stokes the demand for more arms by both the government and non-state actors to maintain security. While the government increases its stock through importation and local manufacture via the Defence Industry Corporation of Nigeria (DICON), non-state actors patronize transnational traffickers/migrants and burgeoning unregulated local and artisanal arms manufacturers.

In a bid to address these security dilemmas occasioned by the illicit proliferation of SALWs, the Nigerian state in 2001 embraced two initiatives aiming at countering the proliferation of small arms and light weapons were agreed within the United Nations framework: the legally binding protocol on Firearm to the Vienna Convention against Transnational Organised Crime, and separately, a political document called the Program of Action (PoA) to prevent, combat and eradicate the illicit trade in small arms and light weapons. These agreements, which included a broad range of measures to enhance controls on transfers, availability, and use of small arms, were largely supply-side oriented. Today, there is increasing concern that controlling and regulating SALWs production, transfer, brokering and misuse is likely to meet with scant success if efforts are not made to identify and tackle the conditions that encourage people to acquire and use guns. Indeed, it has been observed that:

A prominent reason for the large numbers of small arms and light weapons in circulation is the vigorous demand for them. Much of that demand is inevitably linked to criminality, individual and collective. In addition, however, demand for SALWs is widely linked to particular social, economic, and political conditions (Ernie Regehr 2004, 3).

Efforts integrating both supply and demand approaches are needed to address the spread of small arms and light weapons effectively. This implies, in particular, extending the scope of action more broadly to dimensions such as insecurity, social and economic deprivation, and human rights abuses. An encouraging step in this direction was the adoption in 2005 by the UN General Assembly of Resolution 60/68, which drew attention to the linkages between development and small arms. Identifying the factors that incite people to acquire a gun and understanding the mechanisms by which the global proportion of gun owners evolve in a population will make small arms reduction efforts more durable and effective. 


\section{CONCLUSION}

The spread of small arms and light weapons is a major policy challenge for the international community. In West Africa, the proliferation of SALWs has remained a topical issue. Small arms and light weapons facilitate and exacerbate conflicts whose result is large-scale migration and displacement of people and families. The paper acknowledged that, while these weapons play a significant role in the exacerbating conflict that exacts enormous human and economic costs, the causes of such conflicts lie in political, economic, ethnic, and religious differences and disparities. These factors are often aggravated by governance-related deficiencies, such as exclusionary and irresponsive policies and lack of or weakness in democratic institutions, respect for rule of law, and human rights observance. The access to porous international borders further compounds the problems of widespread proliferation, illicit trafficking, criminal misuse, and mass importation by migrants.

The paper further reiterated that the level of conflict in Nigeria is increasing the demand for these weapons as many communities who have suffered defeats from other communities as well as fundamentalists (Boko Haram, Fulani herders, armed bandits, criminal gangs) prepare themselves by simply acquiring these arms from local arms dealers/manufacturers and arms traffickers in the name of self-protection. The role of these arms in fuelling conflicts cannot be overstated. Arising from these, the following viable options are proposed to address the issues of migration and arms trafficking that undermined the security of the Nigerian state. First, the Nigerian state needs to demonstrate a commitment not only in policy formulation, endorsement of agreements, and codification but also in a practical effort at implementation which is vital to carry on the responsibilities of providing social and economic security and development for the citizens. Second, the Nigerian government should be proactive in dealing with the rampant cross-border criminal activities that undermine its national security. There is a need to evolve a new approach to border security, land, sea, and air, using modern and sophisticated detection equipment to discourage arms trafficking through the borders by arms dealers/illegal migrants. This approach should include an integrated mix of development interventions for border communities, trained and dedicated border officials as well as an enhanced border situation awareness infrastructure. Put differently, the Federal Government of Nigeria should strengthen border security arrangements through enhanced intra- and inter-state collaboration among security and intelligence agencies in maritime and land border areas to ensure effective tracking and interdiction of SALWs traffickers and/or illegal migrants. Hence, the need by the Nigerian state to intensify effort to faithfully implement existing Conflict Prevention and Peace Building Strategies as contained in the National Policy on Peace and in Chapter II of the constitution. This would help minimize the outbreak and persistence of violent conflicts that stoke arms proliferation. The Federal Government of Nigeria should strengthen 
democratic institutions and processes of governance to enhance social provision for its citizens, who are becoming increasingly frustrated over governance failure, thereby resorting to violent crimes that increase demand for SALWs. It must also extend to an aggressive job creation program for Nigeria's teeming and idle youth who are fast becoming hopeless. 


\section{REFERENCES}

1. Abdel, Fatau Musa. (2002)."Small Arms: A Time Bomb under West Africa's Democratization Process. Vol. IX, Issue 1, The Brown Journal of World Affairs, 2002, pp.107- 205

2. Asuni, Judith (2009). Blood in the Niger Delta. Washington, D.C.: United States Institute of Peace

3. Banko, O.H. (2016). "Global Trends in Arms Proliferation in Third World Countries and the Impending Apocalypse of the human race: A Case Study of Arms Race and Security Challenges in Nigeria". International Journal of Innovative Research and Development, 2016, Vol. 5, Issue 9, p. 192-205

4. Edeko, S. E. (2011). "The proliferation of small arms and light weapons in Africa: A case study of the Niger-Delta in Nigeria". Sacha Journal of Environmental Studies, 1(2), pp. 58-80

5. Ernie, Regehr (2004). "Reducing the Demand for Small Arms and Light Weapons: Priorities for the International Community, Project Ploughshares Working Paper, 04-2, p. 3 www.ploughshares.ca/libraries/working-papers/wp042.pdf

6. GIABA Annual Report. "Threat Assessment of Money Laundering and Terrorist Financing in West Africa", quoting United Nations Police in Abidjan, 2013. pp. 25, 31,39

7. Hazebn, Jennifer M. and Horner Jonas. "Small Arms, Armed Violence, and Insecurity in Nigeria: The Niger-Delta perspective". The Small Arms Survey occasional paper 20, 2007

8. Ibeanu, O. and F. Mohammed (eds.) Oiling the Violence: The Proliferation of Small Arms and Light Weapons in Niger Delta, Abuja: Fredrich Ebert Stiftung, 2006, pp. $1-25$

9. Ibrahim, A. Z. (2012). "North-eastern Nigeria from the $19^{\text {th }}$ century: A unit of historical study". A paper presented at Summit on the History of North-Eastern Nigeria, hosted by the Taraba State University, Jalingo in conjunction with the Historical Society of Nigeria, held on $2^{\text {nd }}-5^{\text {th }}$ September 2012, pp 1-19

10. Imobighe, T. A. (1986) The OAU, African Defence, and Security. Benin and Owerri: Adena Publisher, p. 16

11. Imobighe, T.A. (2003) "Civil Society and Ethnic Conflict Management in Nigeria". Ibadan: Spectrum Books Limited, pp. 36

12. Institute for Economics and Peace, Global Terrorism Index: Measuring and understanding the Impacts of Terrorism. Sydney: Institute for Economics and Peace, 2005, p. 4

13. Kegley, C. W., \& Gregory, A. R. A Multipolar Peace? Great Power Politics in the Twenty-First Century. New York: St. Martins Press, 1994 
14. Kennan, G. F. (1954). Realities of American Foreign Policy. Princeton, N. J.: Princeton University Press, p. 16

15. Ladan, M.T. (2012). "Impact of insecurity in the Northon Internally Displaced People and Migration Flows between Nigerian and Neighbouring Countries". A paper presented at the Forum of European Working Group on Migration and Development, EU Meeting Room 1, Portakubin, Abuja-Nigeria, 2012, pp. 1- 26

16. Lamptey, A.A. (2011) "Tackling the Aftermath of Libya's 'Arab Spring': Addressing the Small Arms Issue". Kofi Annan International Peace Keeping Training Centre, 2011

17. Lamptey, A. A. (2013). "Rethinking Border Management Strategies in West Africa: Experiences from the Sahel", Kofi Annan Centre for International Peace Keeping Training, 2013, p. 1-4

18. Langumba, K.F. (2010). "Small Arms and Light Weapons in West Africa". A Stocktaking Disarmament Forum. In.V. Keritin (ed.). The Complex Dynamics of Small Arms inWest Africa, Geneva: United Nations Institute for Disarmament Research (UNIDR)

19. Malam, B. (2014). "SmallArmsandLightWeaponsProliferationandits Implicationfor WestAfricanRegionalSecurity". International Journal of Humanities and Social Sciences, 2014, Vol. 4(8), pp. 260 - 269

20. Morgenthau, Hanns J. (1948). Politics among Nations. New York: Knopf, pp. 43

21. Nyako, A. M. (2015). "Northeast Development Commission", A concept note on North East Development Commission: An Institutional Framework for a sustainable solution to the Northeast National Security Challenges: Adamawa Central, Adamawa State, May 2015, pp. 1-22

22. Okafor, G. I. (2017). "Arms Tracing and the Niger-Delta Amnesty Program: Dilemma, Opportunities, and Lessons for Improving Security in Nigeria". In Paul A. Gwaza and Efem N. Ubi (eds.) Nigeria in Global Governance, Peace and Security. Okoye Honey-bees Ltd., 2017, pp. 425-455

23. Olasile, R. S. (2015). "Boko Haram: The Menace of Small Arms and Light Weapons Proliferation in Nigeria".International Journal for Education Research (USA), Vol. 1(1), 2015, pp. 16-33

24. Onwuka, O. (2010). "Territoriality, Arms Trade, and Sub-Regional Security". InC. Bassey \& 0 . 0 .

25. Oshita (eds.). (2010). Governance and Border Security in Africa. Calabar: University of Calabar Press, pp. 175-188

26. Oshita, O.O. (2010). "The Arms Trade and Common Security: The Case of SALWs in West Africa". InC. Bassey \& O.O.Oshita (eds.) Governance and Border Security in Africa. Calabar: University of Calabar Press, 2010 pp. 167-174

27. Robert Keohane and Joseph Nye (eds.). (1971). Transnational Relations and World Politics, Cambridge Mass: Harvard University Press, S. Krasner (ed). International 
Regimes, Ithaca: Cornell University Press, 1983; V. Rittberger (ed.) Regime Theory and International Relations, Oxford: Clarendon Press, 1993 and O. Young, International Cooperation: Building Regimes for National Resources and the Environment, Ithaca: Cornell University Press, 1989, p. 159

28. Rosenau, J.N. (1990). Turbulence in World Politics: $A$ Theory of Change and Continuity. Princeton: Princeton University Press

29. Small Arms Survey, YearBook, HEL, Geneva, 2010, pp. 101

30. Theophilus, O. A. (2019). "Contextualising the proliferation of small arms and light weapons in Nigeria: A threat and risk analysis, 1990-2015. An unpublished thesis presented to the Faculty of Arts, University of Calabar, Nigeria, in partial fulfillment of the requirements for the degree of Doctor of Philosophy (Ph.D.) Peace and Conflict Studies, 2019, pp. 1-161

31. Theophilus, O. A. (2019). "The Versailles peace treaty and post-conflict resolution in Europe and the world," International Journal of Scientific and Engineering Research, Volume 10, Issue 11, November 2019, pp. 830-837

32. Theophilus, O. A. (2020). "Human security Challenges and the Developmental State: The Nigerian Experience", International Journal of Innovative Research in Technology, volume 7 issue 1, June 2020, pp 542-553.

33. Waltz, K. (1979). Theory of International Politics. New York, pp. 117 